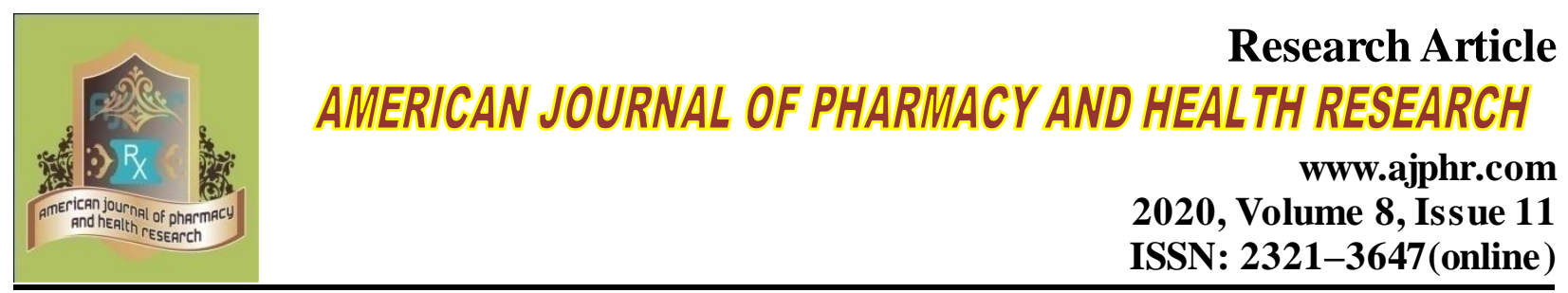

\title{
Preparation and Evaluation of Immunity Boosting Rasayan Kvatha
}

\author{
Satish B. Nirmal ${ }^{*}$ \\ Kaumarbhritya-Balrog Department, Matoshri Asarabai Darade Ayurved College, \\ Babhulgaon, Tal. Yeola, Dist. Nashik, Maharashtra, India
}

\begin{abstract}
Very booming now a day pandemic disease is COVID-19 worldwide caused more than 1.21 million deaths and may expecting more in coming days. COVID-19 caused by Novel CoV (Corona Virus)-2019 and mainly affects respiratory system. In Ministry of AYUSH guidelines suggested to take a 'health drink as; herbal tea/ decoction (Kadha) made from Tulsi (Basil), Dalchini (Cinnamon), Kalimirch (Black pepper), Shunthi (Dry Ginger) and Munakka (Raisin) - once or twice a day. In current research work the immunity boosting rasayan kvatha and evaluation did. The various physiochemical parameter like $\mathrm{pH}$, Specific gravity, viscosity etc determined for three sample preparation. AST study also carried out for all prepared preparation and stable formulation (F3) tested for antimicrobial study against Bacillus subtilis and Staphylococcus aureus. The F3 formulation found to be stable and shows antimicrobial activity against tested pathogens.
\end{abstract}

Keywords: Immunity, Kvatha, Tulsi, Evaluation, Antimicrobial.

*Corresponding Author Email: satish.nirmal2005@gmail.com

Received 10 October 2020, Accepted 04 November 2020

Please cite this article as: Nirmal SB., Preparation and Evaluation of Immunity Boosting Rasayan Kvatha. American Journal of Pharmacy \& Health Research 2020. 


\section{INTRODUCTION}

Various epidemic respiratory diseases emerges now a days, common cold, influenza, flu, pneumonia, whooping cough etc. Very booming now a day pandemic disease is COVID-19 worldwide caused more than 1.21 million deaths and may expecting more in coming days. COVID-19 caused by Novel CoV (Corona Virus)-2019 and mainly affects respiratory system (Ahad HA., et al. 2020) ${ }^{1}$. Mostly in various epidemic respiratory diseases it is suggested that enhance the immunity by regular exercise, food and supportive lifestyle. Making healthy lifestyle choices by consuming nutritious foods and getting enough sleep and exercise are the most important ways to boost our immune system. In addition, research has shown that supplementing with certain vitamins, minerals, herbs, and other substances can improve immune response and potentially protect against illness (Chindarkar P., 2020) ${ }^{2}$. The Ministry of AYUSH has recommended the some self-care guidelines as preventive measures and to boost immunity with special reference to respiratory health (Anonymous; 02/06/2020) ${ }^{3}$. In that guidelines they also suggested to take a 'health drink as; herbal tea/ decoction (Kadha) made from Tulsi (Basil), Dalchini (Cinnamon), Kalimirch (Black pepper), Shunthi (Dry Ginger) and Munakka (Raisin) once or twice a day. Add jaggery (natural sugar) and / or fresh lemon juice to your taste, if needed.' (Anonymous; 13/07/2020) ${ }^{4}$.

The medicinal plants like tulsi, lemongrass, lavang, sunthi, dalchini, kalimiri and haldi have well known for immunity booster/enhancer. In current research work author prepare the immunity boosting rasayan kvatha and evaluated it first time. In present study ingredient selected on basis of their individual proven pharmacological study like Tulsi plant and turmeric rhizomes known for immunity boosting, lemongrass plant, clove buds, dry ginger, cinnamon bark and black pepper consist terpenoids and they are have a antimicrobial activity.

\section{MATERIALS AND METHOD}

Rasayan kvatha is prepared by slight modification in Charaka Samhita, sutrathana Adhaya 4 ; 8 1/2- .All the plant materials were coarsely powder, weighed separately as per Table 1 then boiled with water to make decoction and reduced to one- fourth. Resulting solution filtered, labelled and stored at room temperature for further evaluation.

Table 1: Immunity Boosting Rasayan Kvatha

\begin{tabular}{llllll}
\hline Ingredient & & & Qty (g) & & \\
Common name & English Name & Biological Source & F1 & F2 & F3 \\
\hline Tulsi & Ocimum & Ocimum sanctum & 10 & 10 & 10 \\
Lemongrass & Lemongrass & Cymbopogon citratus & 10 & 10 & 10 \\
Lavang & Clove bud & Eugenia caryophyllum & 5 & 2.5 & 1
\end{tabular}




\begin{tabular}{llllll} 
Sunthi & Dry Ginger & Zingiber officinale & 8 & 4 & 2 \\
Dalchini & Cinnamon & Cinnamum zeylanicum & 2 & 2 & 2 \\
Kalimiri & Black Pepper & Pipper nigrum & 2 & 1 & 1 \\
Haldi & Turmeric & Curcuma longa & 3 & 2 & 2 \\
Jagerrry & & & q.s & q.s & q.s \\
Water & & & $100 \mathrm{ml}$ & $100 \mathrm{ml}$ & $100 \mathrm{ml}$ \\
\hline
\end{tabular}

\section{Physicochemical Parameter}

Rasayan kvatha was evaluated for various physicochemical parameters such as physical appearance, $\mathrm{pH}$, Specific Gravity and viscosity. For determination of $\mathrm{pH} 10 \% \mathrm{v} / \mathrm{v}$ solution prepared and specific gravity determined by specific gravity bottle (Khandelwal KR; 2005, Kokate CK; $1994)^{6,7}$. For determination of viscosity Ostwald's viscometer used.

\section{Accele rated Stability Testing (AST)}

Stability testing of the prepared rasayan kvatha was performed on keeping the samples at accelerated temperature conditions. Nine portions (F1, F2, F3 x 3=9) of the rasayan kvatha were taken in amber colored glass bottles and were kept at accelerated temperature at $4^{\circ} \mathrm{C}$, Room temperature and $47^{\circ} \mathrm{C}$ respectively (Kumar SP, Nayak DP; 2013) $)^{5,8}$. The samples were tested for all the physicochemical parameters, turbidity and homogeneity at the interval of $24 \mathrm{hr}, 48 \mathrm{hr}$ and $72 \mathrm{hr}$ to observe any change.

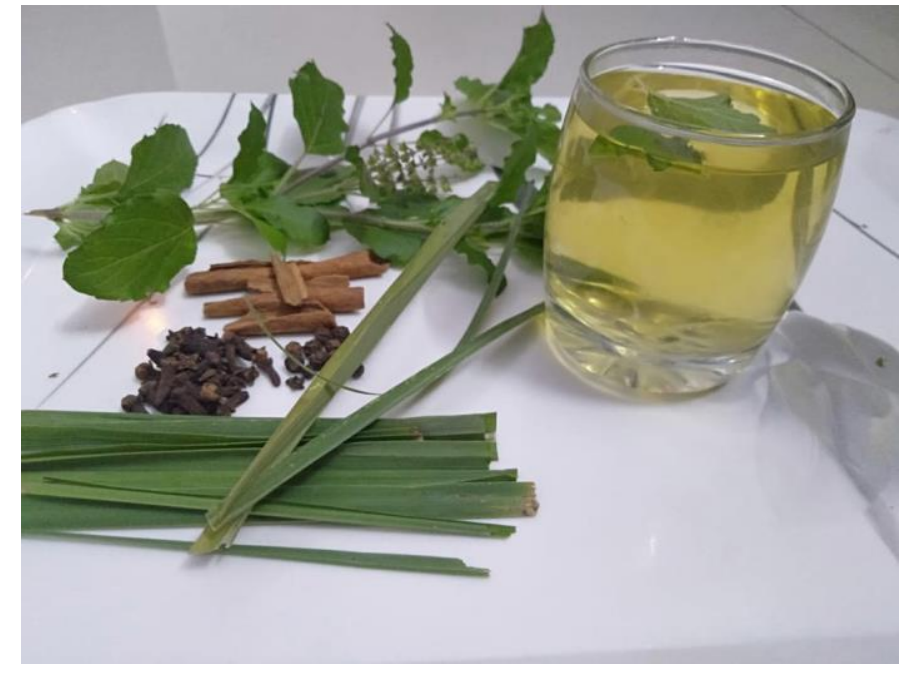

Figure 1: Rasayan Kvatha

\section{Antimicrobial Study}

The formulations those were found to be stable in AST will take for antimicrobial study. The screening of anti-microbial efficacy of the rasayan kvatha was aseptically performed on Bacillus subtilis and Staphylococcus aureus by using Dip well Agar Diffusion Technique. A well was prepared in the plates (containing $15 \mathrm{ml}$ of Nutrient and MacConkey agar medium respectively for both bacteria's). $100 \mu \mathrm{l}$ of the test compound (rasayan kvatha) was introduced into the well. The 
standard antibiotic discs like streptomycin were used as a standard. The plates were incubated overnight at $37^{\circ} \mathrm{C}$. Efficiency of rasayan kvatha was determined by measuring the diameter of zone of inhibition (Mandal SM., et al., 2007) ${ }^{9}$.

\section{RESULTS AND DISCUSSION}

The prepared rasayan kvatha was evaluated immediately after preparation and all the tested parameter along with turbidity/homogeneity were compared with the changes in accelerated stability testing (AST), F3 formulation found to be stable (Figure 1). The rasayan kvatha (F3) found to have $\mathrm{pH} 4.5$ and specific gravity $1.1540 \mathrm{~g} / \mathrm{ml}$ (Table 1).

Table 1: Physicochemical Parameters of Immunity Boosting Rasayan Kvatha.

\begin{tabular}{llll}
\hline Parameter & Inference & & \\
& F1 & F2 & F3 \\
\hline Color & Brown & Green & Light green \\
Odor & Aromatic & Aromatic & Aromatic \\
Taste & Sweet & Sweet & Sweet \\
$\mathrm{pH}$ & 4.9 & 4.7 & 4.5 \\
Specific Gravity & $1.1760 \mathrm{~g} / \mathrm{ml}$ & $1.1570 \mathrm{~g} / \mathrm{ml}$ & $1.1460 \mathrm{~g} / \mathrm{ml}$ \\
Viscosity & $0.11 \mathrm{poise}$ & 0.09 poise & 0.09 poise \\
\hline
\end{tabular}

The results of stability study of the final formulation reveal that in F3 rasayan kvatha no changes were noticed in all the tested physicochemical parameter as well as turbidity/homogeneity during $24 \mathrm{hrs}, 48 \mathrm{hrs}$ and 72hrs. Whereas, F1 and F2 formulation shows changes in tested physicochemical parameters (Table-2).

Table 2: AST of Immunity Boosting Rasayan Kvatha

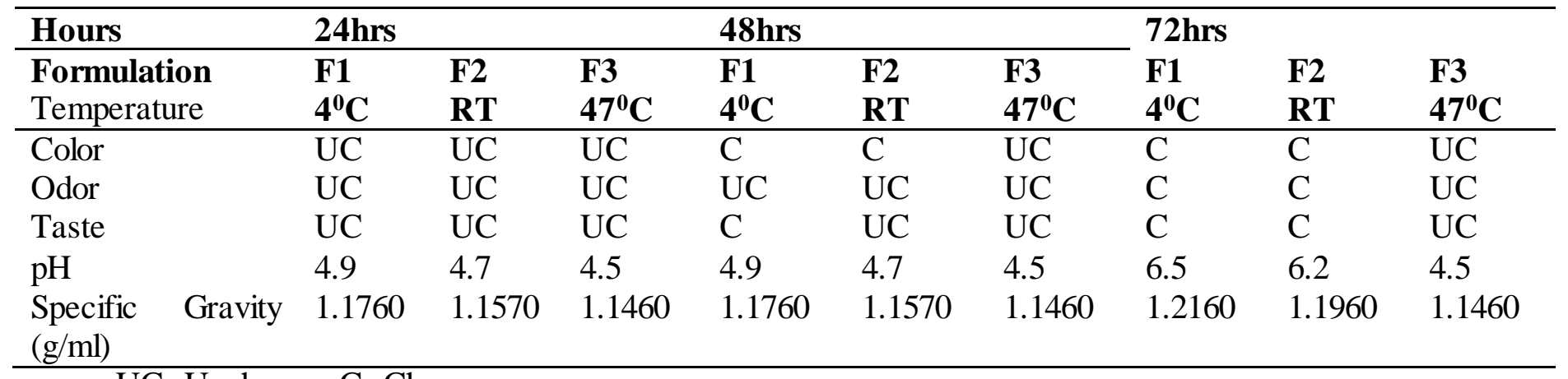

UC- Unchange; C- Change

Table 3: Antimicrobial Studies of Immunity Boosting Rasayan Kvatha

\begin{tabular}{lll}
\hline Microorganism & \multicolumn{2}{l}{ Zone of Inhibition (mm) } \\
& Rasayan kvatha (F3) & Standard \\
\hline Bacillus subtilis & 18 & 14 \\
Staphylococcus aureus & 16 & 21 \\
\hline
\end{tabular}

Preliminary antimicrobial activity screening tests observations were shown in Table 3. Rasayan 
kvatha formulation proved to be beneficial with excellent activity against all the tested microorganisms.

\section{CONCLUSION}

This preliminary in-vitro study demonstrated that immunity boosting rasayan kvatha was effective against pathogenic bacteria. From the result we can say that the rasyan kvatha is good in appearance, stable and acceptable. On basis of results we can further conclude that present formulation may be effective against various respiratory pathogenic microbes like available formulation in market. No doubts further research like toxicity study and supporting preclinical trials for immunity boosting required claiming present work in market. But in researcher in this field use this work as a primary step in this direction.

\section{ACKNOWLEDGEMENT}

The author is thankful to the college management for the encouragement and support for conducting study.

\section{REFERENCES}

1. Ahad, HA., Chinthaginjala, H., Bhupalam, PK., Sharrvani, MVK., Chakrakala, N., Somarajan, AM. Savage Coronavirus: Things to Know Being a Health Care Person. Inter. J. PharmaO 2 ; 2(1) 2020:100-103.

2. Chindarkar, PV. Immunity Booster Supplements to Fight against Viral Infection with Prominence on COVID-19: A Review. Inter. J. PharmaO 2 ; 2(3) 2020:195-203

3. Anonymous. https://www.narayanahealth.org/blog/boost-immune-system-againstcoronavirus-covid-19-infection/ retrieved on 01/06/2020.

4. Anonymous. https://www.mohfw.gov.in/pdf/ImmunityBoostingAYUSHAdvisory.pdf retrieved on 13/07/2020.

5. Kumar SP, Nayak DP. Development and evaluation of poly herbal syrup from some herbs used as expectorant. World Journal of Pharmacy and Pharmaceutical Sciences, Vol 2 (5), 2013: 3848-3853.

6. Khandelwal KR. Practical Pharmacognosy techniques and experiments. Nirali Prakashan, Pune, Ed ${ }^{\mathrm{n}}$. 13, 2005:130-149.

7. Kokate CK. Handbook of Practical Pharmacognosy. Vallabh Prakashan, New Delhi, Edn 4, 1994:58-136.

8. Ghurghure, SM., Dhange AA., Kamalapure, NR., Kate. SN, Katkar, AR., Katta, 
AV., Kattimani, CU and Kattimani, SG. Formulation and Evaluation of Herbal Hand Wash

Gel using Nerium oleander. Research J. Topical and Cosmetic Sci., 2019; 10(1):01-06.

9. Mandal, SM., Mondal, KC., Dey S., and Pati, BR. Antimicrobial activity of the leaf extracts of Hyptis suaveolens (L.) poit. Indian J Pharm Sci, 2007; 69 (4): 568-569.

AJPHR is

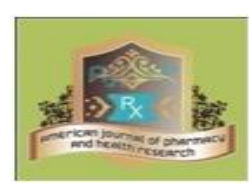

Peer-reviewed monthly

Rapid publication

Submit your next manuscript at editor@ajphr.com / editor.ajphr@gmail.com 